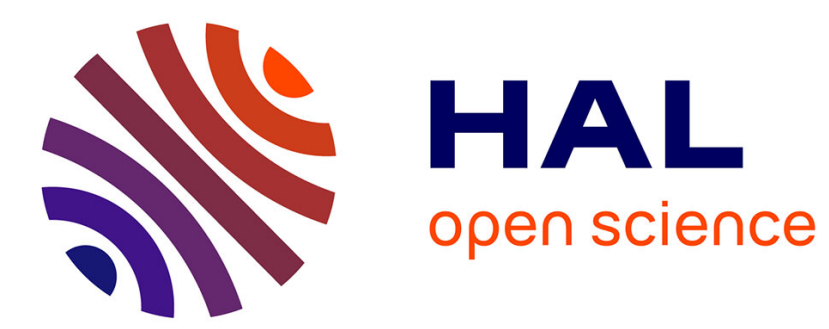

\title{
Four Myths and a Financial Crisis
}

Radu Vranceanu

\section{- To cite this version:}

Radu Vranceanu. Four Myths and a Financial Crisis. 2009. hal-00554704

\section{HAL Id: hal-00554704 \\ https://essec.hal.science/hal-00554704}

Submitted on 11 Jan 2011

HAL is a multi-disciplinary open access archive for the deposit and dissemination of scientific research documents, whether they are published or not. The documents may come from teaching and research institutions in France or abroad, or from public or private research centers.
L'archive ouverte pluridisciplinaire HAL, est destinée au dépôt et à la diffusion de documents scientifiques de niveau recherche, publiés ou non, émanant des établissements d'enseignement et de recherche français ou étrangers, des laboratoires publics ou privés. 


\section{CENTRE DE RECHERCHE}

B e yond Education*

Four Myths and a Financial CRisis

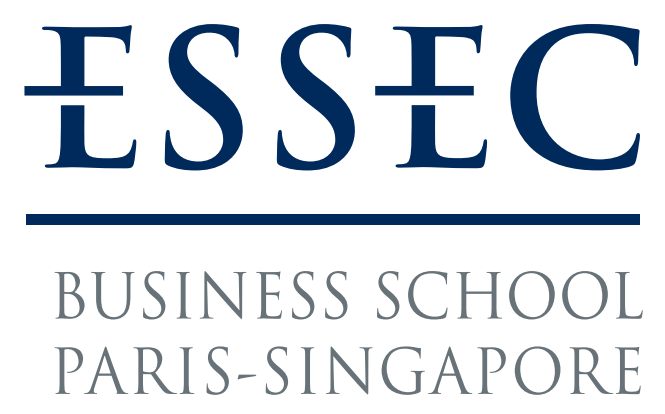


Il est interdit de reproduire ce document ou d'en citer des extraits sans l'autorisation écrite des auteurs.

It is forbidden to quote all or part of this document without the written consent of the authors.

- DR 09006 -

\title{
Four Myths and a Financial Crisis
}

\author{
Radu VRANCEANU*
}

September 2009

Update: June 2010

\footnotetext{
"Department of Economics, ESSEC Business School, Avenue Bernard Hirsch, BP 50105, 95021 Cergy Cedex, France.

Email: vranceanu@essec.fr
} 


\title{
Four Myths and a Financial Crisis
}

\begin{abstract}
:
The main driving force of the financial crisis of 2007-2009 was a rapid deterioration of the trust of private agents in the quality of financial institutions. In turn, this loss of confidence entailed the collapse of several key asset markets and a sharp decline in the other asset prices. This paper surveys the critical moments of the crisis, puts forward some of the shock amplifying mechanisms and comments on the effectiveness of various policy measures. The conclusion opens the debate on what structural changes in the existing financial architecture are required to contain such crises in the future.
\end{abstract}

\section{Key-Words:}

- Banking Sector

- Economic Myths

- Economic Policy

- Financial Crisis

- Trust

\section{RESUME :}

L'article retrace les moments critiques de la crise financière 2007-2009, étudie les mécanismes de propagation des chocs, évalue les politiques économiques mises en œuvre pour faire face à cette crise.

\section{Mots-clés :}

- Banque

- Confiance

- Crise financière

- Equilibre multiples

- Mythes économiques

- Politique anti-crise

JEL Classification : E65, G20 


\title{
Four Myths and a Financial Crisis
}

\author{
Radu Vranceanu \\ ESSEC Business School, \\ PB 50105, 95021 Cergy (Paris), France \\ E-mail: vranceanu@essec.fr
}

26.06.2010

The main driving force of the financial crisis of 2007-2009 was a rapid deterioration of the trust of private agents in the quality of financial institutions. In turn, this loss of confidence entailed a sharp decline in many asset prices and brought to their knees several large financial institutions with centennial tradition. This paper surveys the critical moments of the crisis, presents some of the shock amplifying mechanisms and comments on the effectiveness of various policy measures. We point out four conceptual myths that did not survived to this crisis. The conclusion opens the debate on what structural changes in the existing financial architecture are required to contain such crises in the future.

Keywords: Financial crisis; Trust; Economic myths; Banking sector; Economic policy.

JEL Classification: E65, G20

This is a preprint of an article accepted for publication in the Thunderbird International Business Review, Wiley Publishers, March 2011, Vol. 52/2. 


\section{Introduction}

This last crisis that some observers refer to as the Great Recession began in the summer of 2007 with reassessment of the risk on subprime American mortgage loans, then turned into a genuine banking system crisis in the US and Europe, ending up as a full-blown real economic crisis affecting most countries in the world by late 2008. ${ }^{1}$ Overall, in 2009 the GDP has declined by $2.5 \%$ in the United States, 5.3\% in Japan and 3.9\% in the Euro Area. Unemployment reached levels not seen since the major oil shocks in the 70s, and the fiscal position of many developed countries deteriorated dramatically. The situation is well summarized by Miller and Stiglitz (2010, p.500), "From 2007 to 2009 a chain of events, beginning with unexpected losses in the US-subprime market, was destined to bring the global financial system close to collapse and to drag the world economy into recession".

There have of course been other banking crises in the past (at least thirty major crises of the type were recorded between 1980 and 1996), generating substantial private and social costs (DemigüçKunt and Detragiache, 1998; Reinhart and Rogoff, 2008). ${ }^{2}$ The 2007-2009 crisis, however, differs from past banking crises not only in its strength and multiple ramifications, but also in its worldwide reach. It provided a lesson of humility for a majority of policymakers and scholars, including the author of this text, who underestimated the size of the accumulated fiscal imbalances and the would-be real consequences of these financial imbalances. The truth is that almost nobody has foreseen this crisis, and we do not refer here to those pessimistic scholars who see a crisis everywhere and anytime. ${ }^{3}$

The period 1985-1995 marked a significant turning point in the organisation of the world economy. An overwhelming process of liberalisation of movements of capital was set in motion, initially in developed countries then extending to developing countries. At the same time, new financial instruments such as derivatives and structured products were created, with the aim of hedging against an ever-broader range of risks. The sophistication of these products grew constantly, as did trading volumes.

While this powerful expansion in the financial market over the last twenty years has fostered worldwide growth through better resource allocation in time and the creation of new opportunities for risk diversification, it is also contributed to increase economic instability, by calling for a more substantial role for people's beliefs in structuring reality itself. Indeed, the nature of the "commodities" traded on this market is highly specific. In very general terms, the financial market is defined as the place where resources are traded over time; those currently in possession of surplus resources make them available to businesses that have nice investment opportunities but lack those resources, in exchange for the promise of receiving more resources at a later date. Trade may take place directly through securities such as stocks and bonds, which transfer rights to future remuneration directly to the purchaser, or through the intermediary of specialist financial institutions (banks) that receive resources on deposit and grant loans.

There is an element of uncertainty inherent to all trade in resources over time, as naturally any promise due to be fulfilled in the future carries a risk of default. The higher the risk, the higher the premium required by lenders in addition to a risk-free interest rate. But the price of risk has an impact on the amount of risk. For instance, when a firm needs to borrow to finance its development, if lenders assess the risk of default as low, they claim a small interest rate, and chances of the

\footnotetext{
${ }^{1}$ The early signals of the troubles to come were recorded in February 2007 when HSBC and New Century Financial called for greater than expected loss provision on their loan portfolio (Pomfret, 2010).

${ }^{2}$ In particular, the sequence of events in this crisis bears strong similarities to the crisis that hit the banking sector in Sweden, Norway and Finland in the late 1980s. See Englund (1999).

${ }^{3}$ In the early 2000s, many economists were worried about the large trade deficit of the US and the risks that a sharp devaluation of the US currency would pose: this scenario never materialized.
} 
borrowing firm to repay the loan and pay the agreed interest are high. If on the other hand lenders assess the risk as high and ask for a high interest rate, the borrowing firm will find it difficult to honour its obligations and, ex post, the assessment of the risk as high will also turn out to be right. This simplified illustration demonstrates an important development in contemporary macroeconomics - the concept of multiple equilibria. From this perspective, economic situations, that for simplicity's sake we can refer to as "good" or "bad", are both possible, and materialisation of either depends to a large extent on the beliefs of economic agents (see also Stiglitz, 2010). Furthermore, a sudden deterioration of these beliefs can shift the equilibrium from the good to the bad situation, even if nothing affected the so-called fundamentals of the economy.

From the multiple equilibria perspective, the 2007-2009 crisis has been characterised by sharp, rapid deterioration in the economic agents' perception of the quality of firms in the financial sector, and the quality of the products they manufactured and sold. It can thus be defined primarily as a crisis of trust or confidence. In practice, the trademark of such a crisis is the disappearance of buyers (for various goods and assets), and with them the liquidity so badly needed by firms to meet their shortterm commitments (Krishnamurthy, 2009). In turn, the shortage of liquidity stemming from pessimistic expectations has dramatic consequences on financial institutions that restrain from taking risks, thus do not longer fulfil their social mission.

It should be noticed from the outset that economists were victims of a dangerous myth that prevented them to properly evaluate such macroeconomic risks. Hundreds of studies used the multiple equilibrium approach to explain exchange rate and financial crises that hurt the developing world in the last thirty years. Yet, when it turned to developed countries, economists seem to have a blind faith in that the "bad" equilibrium could never materialize, allegedly because rich countries have much a better governance than developing countries.

One specific form of multiple equilibria are asset price bubbles. In a bubble, the price of an asset at one moment in time no longer depends on the discounted stream of future payments but on the expectation that its price will go up. If all agents form similar expectations, they buy the asset and its price goes up, thus validating the initial out-of-fundamentals beliefs. As no price can go up indefinitely, sharp and wide downside adjustments are the only possible outcome; unfortunately, no model can forecast the precise moment when the adjustment will take place. For years, under Alan Greenspan's presidency, the official position of the Fed (the US central bank) was to let markets behave, and be ready to intervene once that the bubble bursts. By 2004, Alan Greenspan and the Fed officials became aware that something ugly is happening with housing prices, yet they underestimated the size of the required intervention, and did not realized how limited was their capacity to react should they be confronted with a major disruption of financial markets. In a representative quote, Alan Greenspan stated: ${ }^{4}$

\begin{abstract}
"In a related concern, a number of analysts have conjectured that the extended period of low interest rates is spawning a bubble in housing prices in the United States that will, at some point, implode. Their concern is that, if this were to occur, highly leveraged homeowners will be forced to sharply curtail their spending. To be sure, indexes of house prices based on repeat sales of existing homes have outstripped increases in rents, suggesting at least the possibility of price misalignment in some housing markets. A softening in housing markets would likely be one of many adjustments that would occur in
\end{abstract}

\footnotetext{
4 Alan Greenspan, Globalization and innovation, Remarks at the Conference on Bank Structure and Competition, Federal Reserve Bank of Chicago, Chicago, Illinois, May 6, 2004. Online at: www.federalreserve.gov/boarddocs/speeches/2004/200405062/default.htm.
} 
the wake of an increase in interest rates. But a destabilizing contraction in nationwide house prices does not seem the most probable outcome. Indeed, nominal house prices in the aggregate have rarely fallen and certainly not by very much."

This crisis killed this first myth: we know now that high income countries are as prone as low income countries to the curse of multiple equilibria and that asset price bubbles are a problem serious enough to be a matter of concern for policymakers and regulators.

One overwhelming mistake made by economists and other experts in charge with monitoring stability of our economic systems was to pay too little attention to the recent financial innovations, and to the new risks that they imposed on the financial system. Two particular innovations become important vectors of shock propagation and amplification: CDOs (for Collateralized Debt Obligations) and CDSs (Credit Default Swaps). While prior to 2007 almost nobody outside the finance profession has heard about these instruments, during the crisis they made big titles in specialized newspapers. No doubt, economists missed something important. By paying only secondary attention to the recent financial innovations, they paved the way for two other harmful myths to arise, that of a diluting mortgage risk and that of the alleged separation between the financial and the real sector.

The statement made in 2005 by the Fed vice chairman, Roger W. Ferguson describes well the the dominant state of mind: ${ }^{5}$

\begin{abstract}
"Financial engineering has produced many innovations that enable risks to be unbundled and dispersed throughout the financial system. For example, the new technologies of securitization and credit derivatives help banks better manage their exposure to credit risk by offloading some of their risk to institutional investors who appear to be more willing and able to bear it. Dispersing risk widely creates a more resilient financial system, which in turn allows the economy to better weather disruptions."
\end{abstract}

While there is truth in the risk dispersion theory, no one has realized that risk diffusion comes with its own problems. By slicing and then selling bits of dubious assets, everybody ended up by holding some. When these assets started to default, no one could properly assess the magnitude of the contamination. Furthermore, at difference with epidemiology, in financial markets misperceptions magnify the deterioration of the value of the dubious assets themselves. We will turn back to this story after introducing the main facts.

After this crisis, economists will also have to think about their theories. The dominant paradigm in monetary economics and monetary policymaking was developed in the late 1990s as an attempt to rationalize the observed central bank behaviour (for many years now central bankers were steering short-term interest rates with a more or less explicit objective of achieving low inflation) and the new stability of growth and inflation rates in the developed countries, a trend often referred to as "the Great Moderation" (e.g., Giannone et al., 2008; Gali and Gambetti, 2009). ${ }^{6}$

\footnotetext{
${ }^{5}$ Roger W. Ferguson, Asset Price Levels and Volatility: Causes and Implications, Remarks at the Banco de Mexico International Conference, Mexico City, Mexico November 15, 2005. On line at: www.federalreserve.gov/boarddocs/ speeches/2005/ 200511152/default.htm.

${ }^{6}$ Explanations for the Great Moderation vary from a better monetary policy, better inventory and supply chain management, more flexible labor markets, to... good luck.
} 
Among the main contributors to the dominant monetary theory, one can refer to Marc Gertler, Richard Clarida, Jordi Gali and Michael Woodford (see Clarida et al., 1999; Woodford 2003). ${ }^{7}$ The three equation standard model mixed new classical-style intertemporal optimisation by representative agents forming rational expectations, with a broader conception of the economy that owed much to the "Old" New Keynesian thinking (imperfect competition where firms have pricing power and prices are sticky). Many scholars point out that financial intermediations plays little role in this approach (Blanchard, 2009; Miller and Stiglitz, 2010).

If these models describe well the dynamics of the economy when deviations from the equilibrium paths are small, they are not designed to analyze the consequences of a major crisis. In particular, they lack the basic blocks (financial sector) needed to analyze a major break in financial markets and the banking sector. ${ }^{8}$ No surprise that if policymakers interpreted the early signals of the crisis as a mere demand shock, a one percentage point reduction in the target interest rate would have solve the problem, according to results of the basic simulations performed at that time. As an example of extreme optimism with respect to the little relevance of US financial troubles for the Euro area economies, the ECB raised by $1 / 4$ point its interest rates in July 2008 , only four month before the "Lehman earthquake".

Finally, a fourth myth that took a serious blow during this crisis is that of the useless state. As will be shown in the policy section, during the worst moments of the crisis, only the powerful intervention of central banks and governments allowed to restore trust in the financial system, and blocked the emergence of a systemic crisis. Yet this paper is not a plea in favour of "big government". To the contrary, it will be shown how a tolerant attitude toward "fat" financial institutions weakened competition in the banking sector in both the US and Europe and ultimately reduced the resilience of the sector to shocks.

So this crisis taught us that the developed world is not insulated from the risk of quickly deteriorating beliefs, that financial risks cannot be easily spread, that financial shocks do have magnified effects on the real sector, and that during stormy economic periods, governments and central banks can provide a worthy buffer, while in the long run they must protect competition in the banking sector. Whatever the future financial architecture of our societies, it will be grounded in these common sense principles unveiled by this crisis.

Without pretending to provide a comprehensive explanation of the crisis, this paper aims at telling "the story of the crisis" in a concise way, bringing together interesting facts and some theories. After a close examination of the facts (Section 2), policies and regulation (Section 3), the conclusion will open the debate on what have we learnt from this crisis.

\section{Summary of the facts}

This Section aims at presenting the critical moments of the crisis in a chronological order, and to emphasize the most important shock amplification mechanisms.

\subsection{The burst of the real estate bubble and the subprime crisis}

Several factors combined to pave the way for emergence of a real estate bubble in the US in the late 1990s, as property prices rose rapidly. Eventually the price rises became self-perpetuating, as

\footnotetext{
${ }^{7}$ For an introduction to the New-Keynesian macroeconomic model, see Gali (2008).

${ }^{8}$ See Curdia and Woodford (2009) for an attempt to integrate credit market frictions in such a model.
} 
investors were buying houses on the expectation that home prices would further rise, and the prices were rising in response to ever-growing demand. Between 2000 and 2006, the national house price index more than doubled in the US (and regions such as Florida and California saw even higher rises). Among the factors involved were reforms introduced in the 1990s by the US administration to encourage home ownership by poorer households, a sharp decline in mortgage transaction costs due to automatic calculation of the risk category, securitisation which enabled the banks to finance these loans more cheaply, and the US Federal Reserves' extremely lax monetary policy after the dotcom bubble burst in 2001.

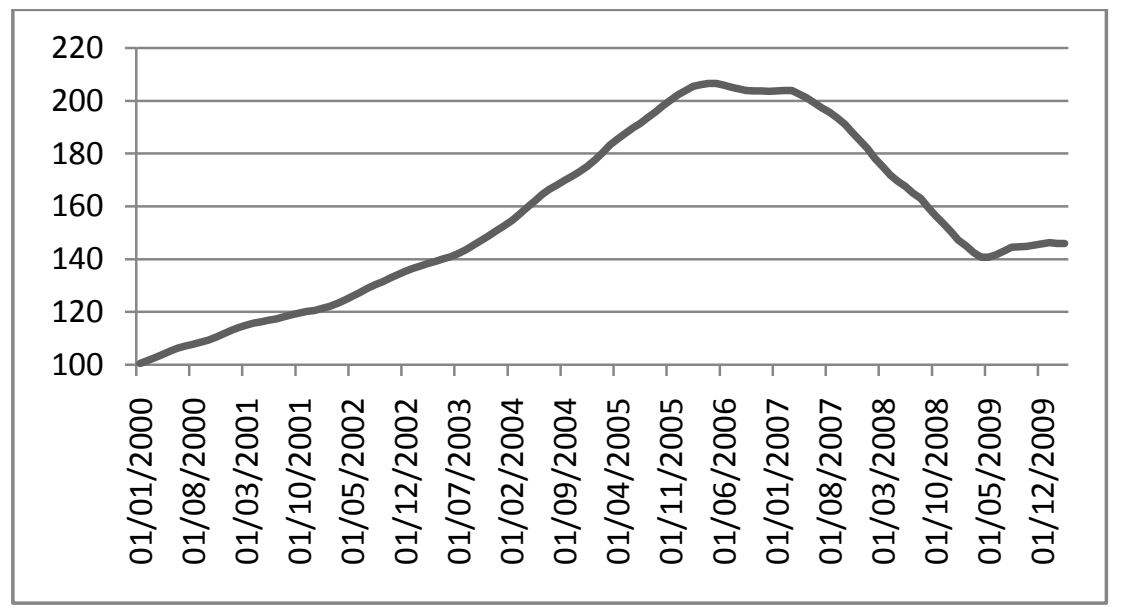

Figure 1. US Case-Shiller Home Price Index 20 city composite, seasonally adjusted. Source: Standard and Poor's

In the US, most mortgages are granted either by non-specialist deposit banks or banks specialising in mortgage lending. The volume of new loans increased year after year, from USD 500 billion in 1995 to USD 3,000 billion in 2006. Until 2003, most new mortgages were "prime conforming" and met strict borrower solvency criteria (income, assets, initial deposit). These loans were then mostly repurchased by two firms specialised in refinancing for mortgage issuers, known generally by their nicknames Freddie Mac and Fannie Mae. ${ }^{9}$ Both are Government Sponsored Entreprises (GSEs) private companies, but with strictly regulated activity - and their debt was implicitly covered by state guarantees. This status enabled them to raise funds on the bond market for years at interest rates close to Treasury bond rates.

In response to policies to encourage private ownership, from the mid 1990s the banks began to grant "subprime" mortgage loans to families with modest, irregular incomes, on terms that appeared tempting at first glance but could turn out to be extremely unfavourable if the base interest rate rose. In 2006, only $36 \%$ of new mortgages were "prime" loans (Kiff and Mills, 2007). Quite rationally, the banks thus sought a way of getting rid of these risks. As Freddie Mac and Fannie Mae were not authorised to repurchase these loans (or only a very small proportion of them), the commercial banks turned to securitisation, as a mean to "get rid" of the risk by transferring it to many investors. The method of securitisation implies that the credit institution groups together loans with a similar profile (maturity, risk category, etc), and then sells them to a special off balance sheet entity created for the purpose. This entity purchases the assets from the principal loan issuer by issuing Mortgage Backed Securities (MBS), i.e. bonds backed by the loans. When the mortgage issuer sells its loans to the special entity, its balance sheet total decreases and in view of its equity and reserve

\footnotetext{
${ }^{9}$ Freddie Mac is "short for" Federal Home Loan Mortgage Corporation, Fannie Mae for Federal National Mortgage Association.
} 
requirements, it can then issue further loans. The bank thus transfers to this entity not only management of the portfolio and the associated profit and loss, but also the risks. It makes an apparently risk-free profit on this transaction in the form of a commission (Diamond and Rajan, 2009; Brunnermeier, 2009).

Interest on MBSs matches the interest on the loans, less administrative expenses. The purchaser of an MBS becomes the owner of the receivables, and agrees to bear (some or all of) the lender's risk of default.

One notable feature of MBSs is structuration. ${ }^{10}$ Take the example of a loan portfolio financed by issuance of MBSs, all through an ad-hoc legal entity. Clearly, the lenders are in varying degrees of solvency and/or will have to cope with varying falls in income in the event of a crisis. For example, for a 100-loan portfolio, the probability of default by one lender is very high, whereas the probability of default by all lenders is practically nil. This means it is possible to segment the entity's liabilities into bond tranches with different levels of exposure to the risk of default. A first tranche (generally called equity) will bear all the initial losses, another tranche (mezzanine) will bear the following losses and so on, until we arrive at a tranche that is practically free of the risk of default, and this tranche can be attributed the highest credit rating, generally expressed as AAA. The riskiest bonds are thus subordinated to the less risky bonds.

Other important players in this crisis become involved at this stage: the ratings agencies. On the whole, the current financial system has handed over the assessment of the credit risk associated with debt instruments to three international agencies, Moody's, Standard \& Poor's and Fitch. Banks engaging in mortgage securitisation asked these agencies for recommendations on the size of the tranches and the guarantees required to achieve the highest proportion of AAA securities. With hindsight, it is surprising that the risk on MBSs - a portfolio of loans - was assessed using the same rating scale as for debt instruments of industrial companies such as General Electric and Boeing. The financial market intermediaries' demand for standardisation was apparently met in a particularly questionable piece of prestidigitation. Ratings agencies have the risks for industrial businesses assessed by their analysts with reference to the firm's past record, whereas for the loan portfolios, they used quantitative forecast models based on untested assumptions regarding the possible correlation of incidences of default inside the portfolio. Furthermore, as the score attributed by rating agencies is supposed to be independent of the business cycle, assessment also required forecasting of possible future developments in the economic climate. At a time when real estate prices were rising, the agencies felt no pressure to take a more pessimistic outlook.

To make things more complex and more opaque, investment banks and large commercial banks such as Citigroup moved into the very profitable business of setting up Structured Investment Vehicle (SIV), as special off balance sheet entities, to purchase various very high-risk MBSs by issuing bonds under the same structuring principle. The balance sheet liabilities of SIVs thus showed bonds named Collateralized Debt Obligations or CDOs, whose highest tranches once again got the top credit rating AAA. Again, the tranches of risk were calculated on the basis of arbitrary assumptions regarding correlation between any default on the various assets in the entity's portfolio.

As already mentioned, another financial instrument that has played a major role in this crisis is the Credit Default Swap (CDS). When first created in the late 1990s, CDSs were based on a simple idea: the aim was to enable the buyer of a bond issued by a given company to hedge against the risk of

\footnotetext{
${ }^{10}$ See Coval et al. (2009) and Ashcraft and Schuermann (2008) for an introduction to the economics of structured finance.
} 
default by that company - the counterparty risk. ${ }^{11}$ This is possible if another agent agrees to bear this risk, in return for remuneration. And so CDSs appeared as over-the-counter contracts between a seller and a buyer of protection against the default by a third party on its debts. The third party (or reference entity) may be a company, a government, a local administration, or an ad-hoc investment vehicle financing the purchase of Asset Backed Securities (particularly MBSs) through the issuance of CDOs. The terms of such contracts range from two to ten years. The contract's notional value is the face value of the bonds covered by this form of insurance. The principal payment is triggered by a credit event. For example, if a firm goes bankrupt, the value of bonds it issued may collapse. ${ }^{12}$ Depending on the type of contract, the seller of the CDS undertakes either to pay the purchaser the difference between the bond's face value and residual value, or pay the full face value in exchange for the bonds concerned. The protection buyer agrees to pay the seller a premium throughout the term of the contract, except in the event of default, in which case payment is suspended.

While ten years ago the notional value of CDSs was negligible, it shot up to a peak of USD 62 trillion at the end of 2007, which was five times the US GDP, or more than worldwide GDP. The massive increase in the volume of CDSs is explained by an increasing need for protection in times of uncertainty, the speculation that developed around the CDS product, and the decentralised nature of the market, making consolidation of cross-hedging impossible. In late 2007 in particular, many banks that had purchased MBSs and CDOs sought to acquire protection by purchasing CDS hedges.

\subsection{From the subprime crisis to the banking crisis}

The first tensions were felt in mid-2006, when the rising trend in US real estate prices abruptly reversed after a series of interest rate rises (Figure 1). A high interest rate and falling prices turned out to be an explosive cocktail, causing a speedy increase in the default rate on subprime mortgages. With this turn of events it became clear that the ratings agencies had greatly underestimated the probability of a real estate market collapse, and that CDOs based on subprime-type loans were considerably riskier than implied by their risk rating. Consequently, the risk rating for many AAA debt backed instruments was suddenly taken down several grades, a step never taken before for industrial corporations' credit ratings (industrial firms are fairly often downgraded, but generally only by one notch at a time).

The vast complexity of credit instruments (which are not necessarily technically complex, but are legally complex due to the diversity of contracts involved) and the "chaotic" growth specific to the bubble had enhanced opacity in financial transaction. Trusting the ratings agencies, the banks involved in production of structured products and the banks that had purchased those products had unquestioningly accepted the attributed risk rating as true. This blind trust is all the more surprising in large banks, which have their own powerful risk analysis centres. When the alarm bells started ringing, it was already too late: the holders of these securities realised with horror that their potential purchasers had vanished and the value of the assets was in freefall.

The US (and British) banks that had participated in MBS and CDO issues with high subprime content had retained a substantial share in their accounts, or had to hurriedly bring the SIVs they had set up back onto their balance sheets. This resulted in a sudden deterioration of their financial position. A

\footnotetext{
${ }^{11}$ Unlike shares, where the holder can resort to derivatives to cover himself against a variation in their value, the only way for a bond holder to protect himself against a foreseen increase in the risk of default was to sell the bond.

12 In normal times, the average rate of recovery is $50 \%$ of face value; this can fall to $20 \%$ in a period of recession.
} 
mortgage lending bank as large as Countrywide, for example, found itself on the brink of disaster and was ultimately absorbed in July 2008 by Bank of America.

But the real trouble began when investors began to ask who in fact owned the dubious assets. Analysts expected to find the US banks in the front line. They realised, as successive financial results for the first quarter of 2008 were released, that several German, French, Swiss, Belgian and other banks had purchased millions of dollars' worth of CDOs of US origin, and were now obliged to set aside significant provisions for impairment losses. These banks had probably been attracted by AAAgrade securities offering a slightly higher interest rate than AAA-grade industrial bonds. Regulation in force in Europe also provided strong incentives for bank to hold AAA assets on their books, irrespective of the composition of these assets.

But how could each bank's degree of ownership in the dubious assets be observed? And ultimately, what was the true value of these assets, for which the secondary market had disappeared in most cases? Obviously, it was very much in the interest of banks with high exposure to this type of asset to play down their problems in order to obtain better financing terms (especially on the interbank market). Of course, good banks claimed that their exposure is low. Yet, as long as there was no "definitive" tool to sort out good from bad banks, doubt created a risk premium that applied to all banks, and harmed in particular the good ones. ${ }^{13}$

The world finally remembered that trust is a bank's most important asset. As long as customers and creditors have confidence in a bank, it can finance its loans and other investments undisturbed. But if that confidence disappears, the bank encounters liquidity difficulties that can turn out to be insurmountable.

The crisis has unveiled a new dimension of the contemporary financial architecture. Over time, banks and the other financial institutions (insurance companies, hedge funds, pension funds, etc) become more interconnected, with an increasing number of financial institutions keeping on their balance sheet assets such as public and corporate bonds as well as CDOs whose value was covered by CDStype insurance sold by other financial institutions. This increased interdependency is a powerful shock amplification mechanism. If some liabilities of one bank guarantee the assets hold by a second bank, any risk on the viability of the former bank has a bearing on the market value of the latter. If one seller of CDS protection is pushed out of the market, all the banks that bought this protection will be directly exposed to the risk of default by the reference entities covered by these CDS.

In an environment of increasing interdependency between banks, default by one bank can bring about default of partner banks, whose default would stress their own partners, etc. In theory, a systemic crisis is defined as a situation in which the individual probability of default increases with the cumulative frequency of default in the sector. The context where a systemic crisis can occur has long been well-known. ${ }^{14}$ Unfortunately, the myth according to which securitisation would enable banks to parcel up and spread mortgage risks to a mass of investors supposed to be more resilient to macroeconomic shocks seems to have undermined the economists' warnings that strict management was required for the risk on bank loans. The principle of spreading the risk is probably appropriate, but the tolerable limit on how much to transfer was far exceeded.

\footnotetext{
${ }^{13}$ See Besancenot and Vranceanu (2010) for a formal model of banking communication in times of crisis that emphasizes how difficult it is for investors to assess the true exposure to risky assets of a given bank from its official messages.

${ }^{14}$ There is a vast body of literature, but we can single out the classic bank run model developed by Diamond and Dybvig (1983), and the interbank market panic model proposed by Rochet and Tirole (1996).
} 
In fact, for a short period in the summer of 2008, there was a tangible risk of bank runs in Europe. As early as February 2008, following massive deposit withdrawals the UK government nationalised Northern Rock, a high leverage bank that was extensively involved in mortgage lending in the US and UK, and decided to raise the guarantee for customer deposits. Under escalating pressure from savers, who were beginning to withdraw their money, Ireland decided in September 2008 to guarantee all bank deposits (a technically impossible commitment as total deposits were equivalent to $200 \%$ of this small country's GDP). This reform led to a flood of deposit transfers from other banks into Irish banks, and so in October 2008, the other European countries had to raise their guarantee levels as well.

As everyone was under suspicion, another phenomenon arose: the interbank market gradually dried up, with the emergence of a substantial spread between the rate on collateralised loans by the central banks and the interbank rate at which banks make uncollateralized loans to each other (short term, particularly 3 months). Banks on both sides of the Atlantic began to have enormous cash flow problems as they ran out of short-term financing sources (they could no longer issue certificates of deposit). The more a bank used short-term debt, the greater its difficulties. Unsurprisingly, the most affected were the large Wall Street investment banks, which had neither stable resources in the form of deposits nor access to Fed financing facilities, and were operating with considerably higher indebtedness than the deposit banks.

\section{BOX: The organization of the banking sectors in the US and Europe}

Following the Great Depression, the US instated a distinction between investment banks and commercial (or deposit) banks. The founding rule of this separation was the Glass-Steagall Act, passed in 1933. In the late period the rule was overcame by many large banks, and was finally abrogated in 1999 by the Gramm-Leach-Bliley Act. By 2007, equity finance transactions (i.e. those undertaken on behalf of other firms, such as IPOs, mergers and acquisitions, bond issues, securitisation) were generally confined to five large Wall Street investment banks (Bear Sterns, Morgan Stanley, Merrill Lynch, Goldman Sachs, Lehman Brothers) and a small number of very large banks with more diversified profiles, such as Citigroup or JP Morgan-Chase. The investment banks did not collect deposits, financing their business growth through their (sometimes enormous) profits, stock issues and above all, huge amounts of debt. On the other side, commercial banks do collect deposits; they vary widely in size, often only operating in a certain regional area, sometimes specialising in specific types of loans: industrial loans, agricultural loans, mortgages, etc. The large banks in Europe, however, have a diversified profile, mixing commercial and investment activities: they collect deposits and issue debt, grant loans and carry out transactions and investment activities on behalf of businesses.

In March 2008, Bear Sterns was the first to be absorbed by JP Morgan Chase. In September 2008, Merrill Lynch was taken over by the leading US commercial bank, Bank of America. But just then a genuine wave of panic was triggered by the collapse of Lehman Brothers. Lehman Brothers was a bank with an impressive portfolio of MBSs and CDOs; at the time, the notional value of the CDSs it had sold was estimated at USD 400 billion. ${ }^{15}$

This panic is easy to understand today, as it looked as though neither the size nor the strength of its network could guarantee the survival of a financial institution. Financial market operators' fears were greatly accentuated by the enormous volume of outstanding CDSs: for the first time, investors began to doubt the ability of sellers of protection to honour their commitments (FASB, 2009), and this had a

\footnotetext{
${ }^{15}$ Once in liquidation, it came to light that Lehman Brothers had hedged against the risk of default of the reference entities, by buying CDSs from other banks; the total value of CDS payments made, net of payments received, was only USD 6 billion, a small amount given the bank's size and quality.
} 
knock-on effect on the perceived financial health of entities that had hedged against default on various assets in their portfolio (such as MBS or CDOs) by buying CDSs.

Reflecting this general loss of confidence, the spread on the interbank market reached new heights (almost two percentage points on 3-month credit in November 2008 - see figure 7) and so did the CDS premium for financial institutions (figure 8). Speculative attacks then shook Morgan Stanley, which in November 2008 saw its stock market value tumble and only stabilise after the US government's promise that it would not let collapse any other large and interconnected financial institution.

Finally, the same month, the surviving investment banks (Morgan Stanley and Goldman Sachs) changed their status to that of a deposit bank, which meant they could collect deposits and obtain refinancing from the Fed, but placed them under stricter ratio requirements and an obligation for greater transparency regarding their transactions and the state of their finances. The traditional investment bank model has not therefore survived this crisis (Pomfret, 2010).

In the meantime, other serious shocks were associated with partial default by insurance companies involved in the production of MBSs and CDOs, such as the monoline insurers Ambac and MBIA, and in particular the US insurance giant AIG. While the traditional divisions of AIG have always been profitable, in the early 2000s the investment arm of the company became extensively involved in the CDS market. The total value of protection sold by AIG to various banks and hedge funds on reference entities with high subprime content was some USD 440 billion. When the CDOs value started to slide down, AIG had to pay the difference between the notional value and the residual value, and saw all its capital melting away. If AIG had gone bankrupt, many banks all over the world would have suffered enormous losses given their own liabilities to third parties. AIG was thus kept alive with massive cash injections from the US government, receiving USD 144 billion in state aid in the period to August $15,2009 .^{16}$

The Government Sponsored Enterprises specialized in mortgage refinancing, Freddie Mac and Fannie Mae, which had gradually increased their amount of subprime loans under political influence, saw their equity melt away and were at serious risk of not being able to roll-on their maturing debt. In September 2008, the government thus took both organisations into public management and committed to an investment that had reached USD 111 billion until January 2010. Meanwhile, in an unusual move, the Fed decided to purchase the bonds issued by them directly (for a maximum of USD 200 billion).

Between July 2007 and the end of 2008, the stock market values of banks and financial institutions fell by approximately $70 \%$ (compared to the general index downturn of $45 \%$ ). Many CEOs were dismissed. Jobs were frozen. With a catastrophic fourth quarter in 2008 (substantial losses), annual profits for close to 8,500 US deposit banks registered with the Federal Deposit Insurance Corporation (FDIC) and some 7,500 European banks were close to zero in $2008 .{ }^{17}$ In the banks, the sector most affected is specific to investment banks and concerns securitisation and structured products. Other sectors, however, stood in relatively good health: the standard deposit and loans business has suffered little and so did foreign exchange and commodity brokerage; mergers and acquisitions also hold up well.

\footnotetext{
${ }^{16}$ See The Toxic Trio, The Economist, August 15, 2009.

17 See Financial Stability Review, June 2009, European Central Bank, www.ecb.int/ pub/pdf/other/ financialstabilityreview200906en.pdf et Quarterly Banking Profile, First Quarter 2009, FDIC, www2.fdic.gov/qbp/2009mar/qbp.pdf.
} 


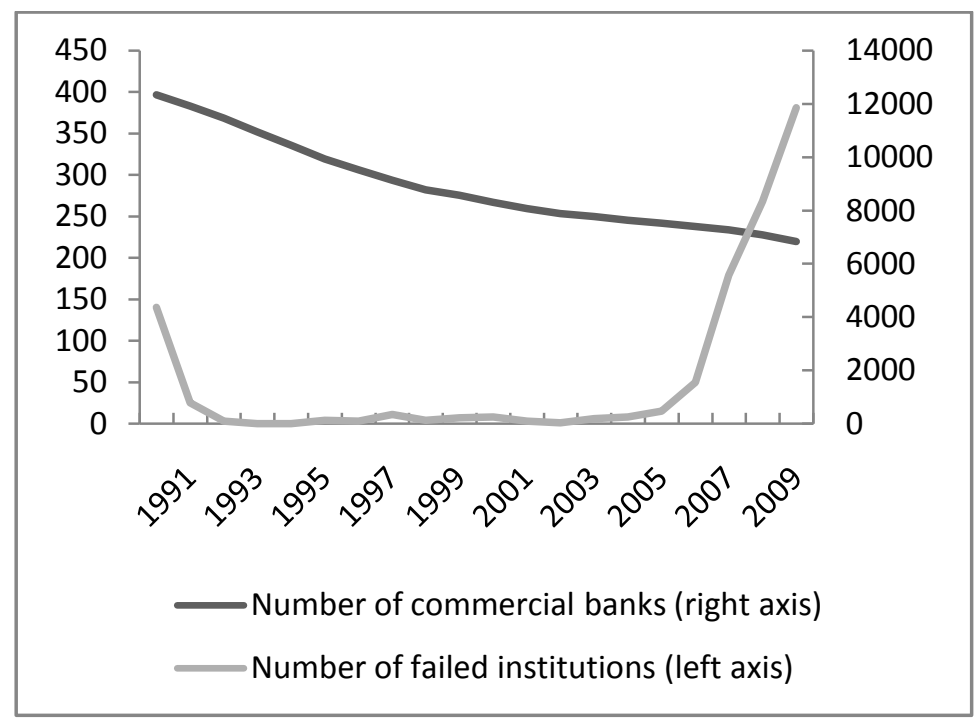

Figure 2. US: Total number of commercial banks registered with the FDIC and number of failed institutions. Source: FDIC Statistical Database

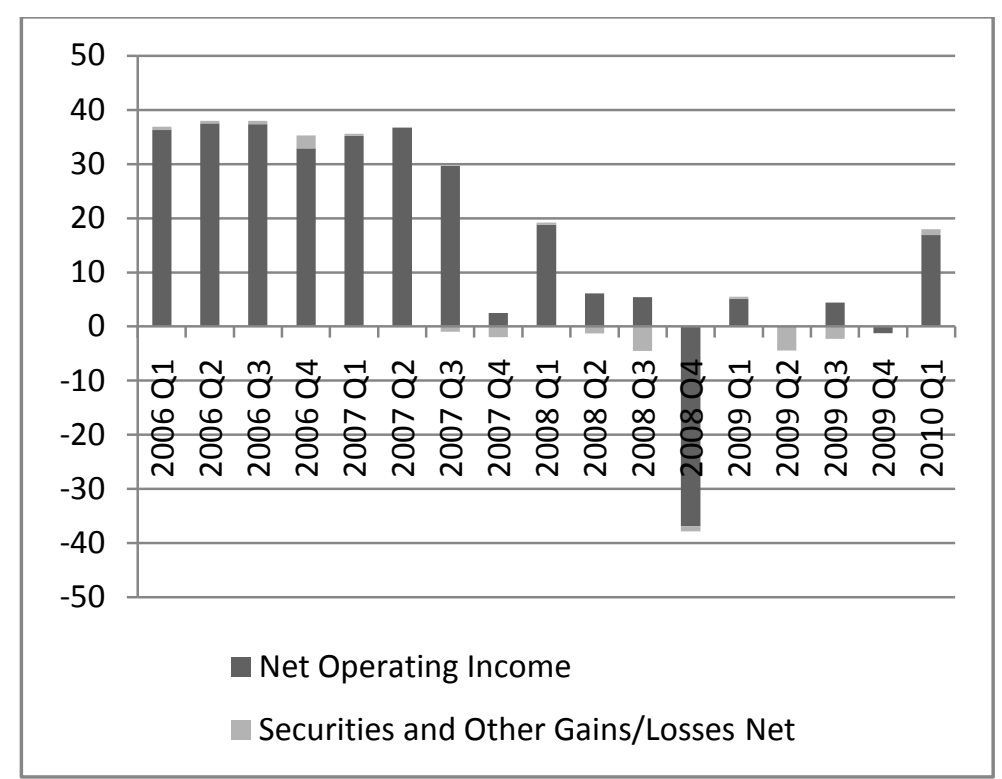

Figure 3. US: Bank quarterly net income in billions of USD. Source: FDIC Quarterly Banking Profile

\subsection{From the banking crisis to the real crisis}

Another economic myth, circulated before and at the beginning of the crisis, put forward the idea of the separation between the financial and the real sector. Economists have long believed that problems in the financial sector could only have a small effect on the real economy and that a slight adjustment to monetary policy would be enough to put things right. As already mentioned in the Introduction, the dominant New-Keynsian macroeconomic model (Clarida et al. 1999; Woodford 2003) used for policy purposes was far from appropriate for simulating the impact of this crisis: not 
only it focused on small deviations from equilibrium paths, but it did not explicitly incorporate the financial sector. ${ }^{18}$

Events showed the optimism behind this second myth to be ill-founded. In 2009, most economies registered GDP declines on a scale not seen since the last World War (real growth rates for 2009 were of $-2.5 \%$ in the United States, $-5.3 \%$ in Japan and $-3.9 \%$ in the Euro Area) End of 2009, unemployment reached $10 \%$ in both the US and the Euro Area. All over the world, inflation fell significantly to a worrying zero, partly because of the decline in oil and commodity prices, but also in response to the collapse in demand.

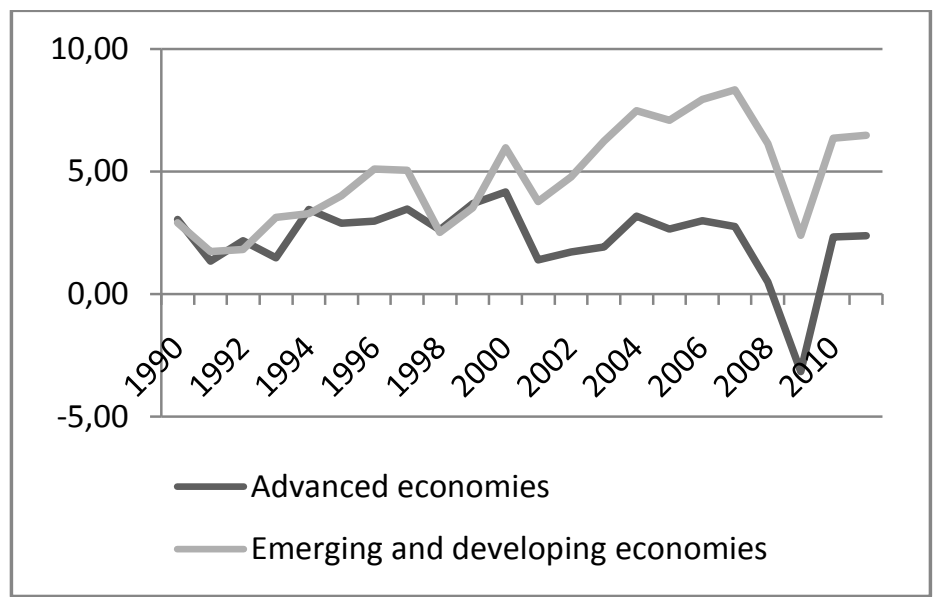

Figure 4. GDP growth rates in annual percent change. Source: World Economic Outlook, IMF 2010.

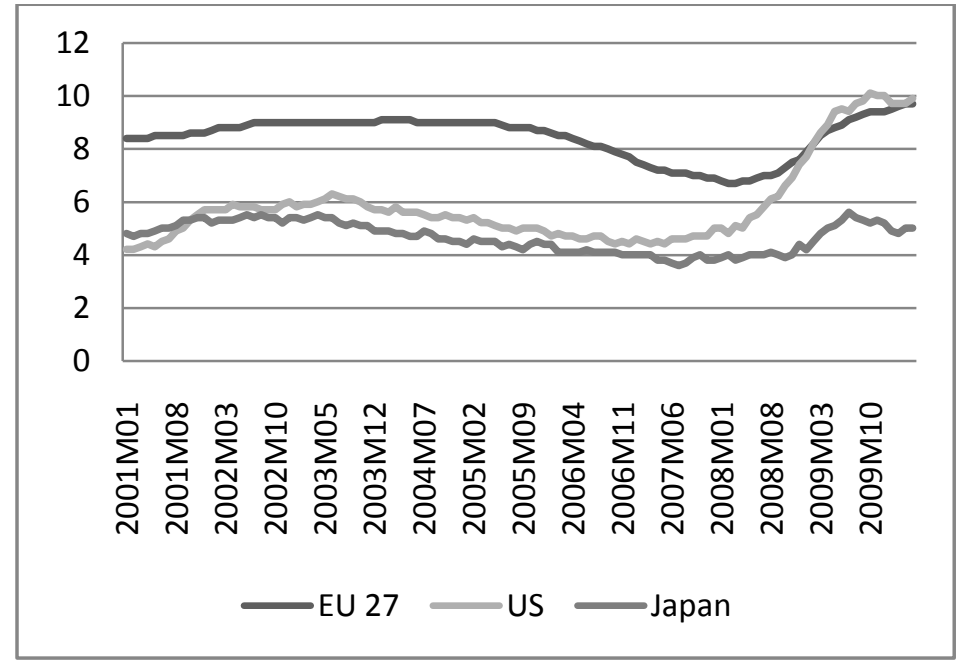

Figure 5. Unemployment in percent of labor force. Source: Eurostat

\footnotetext{
${ }^{18}$ Its microeconomic foundations are also subject to criticism. According to Blanchard (2010), two of its three main equations are just wrong. To find a relevant analysis of interactions between the financial sector and the real sector, it may be necessary to go back to the 1970s writings of Hyman Minsky.
} 
The main factor behind the real crisis should be sought in the psychology of the economic agents. All the modern theories support Keynes' intuition that the actual economic outcome depend to a large extent on individuals' state of mind. More in detail, if businesses and households expect a downturn in the near future, the former stop investing, and the latter stop spending and save more. The resulting higher unemployment and excess production capacities simply accentuate the initial pessimism and a vicious circle forms.

Between mid-2007 and the end of 2008, most of the major US and European stock market indexes receded by approximately $45 \%$. The plummeting value of assets in the form of equities may also encourage households to save more and therefore spend less. This negative "wealth effect" should have been more pronounced in the US than in Europe, for in the US much of the money put aside for pensions is managed by pension funds which themselves invested some of their capital in equities.

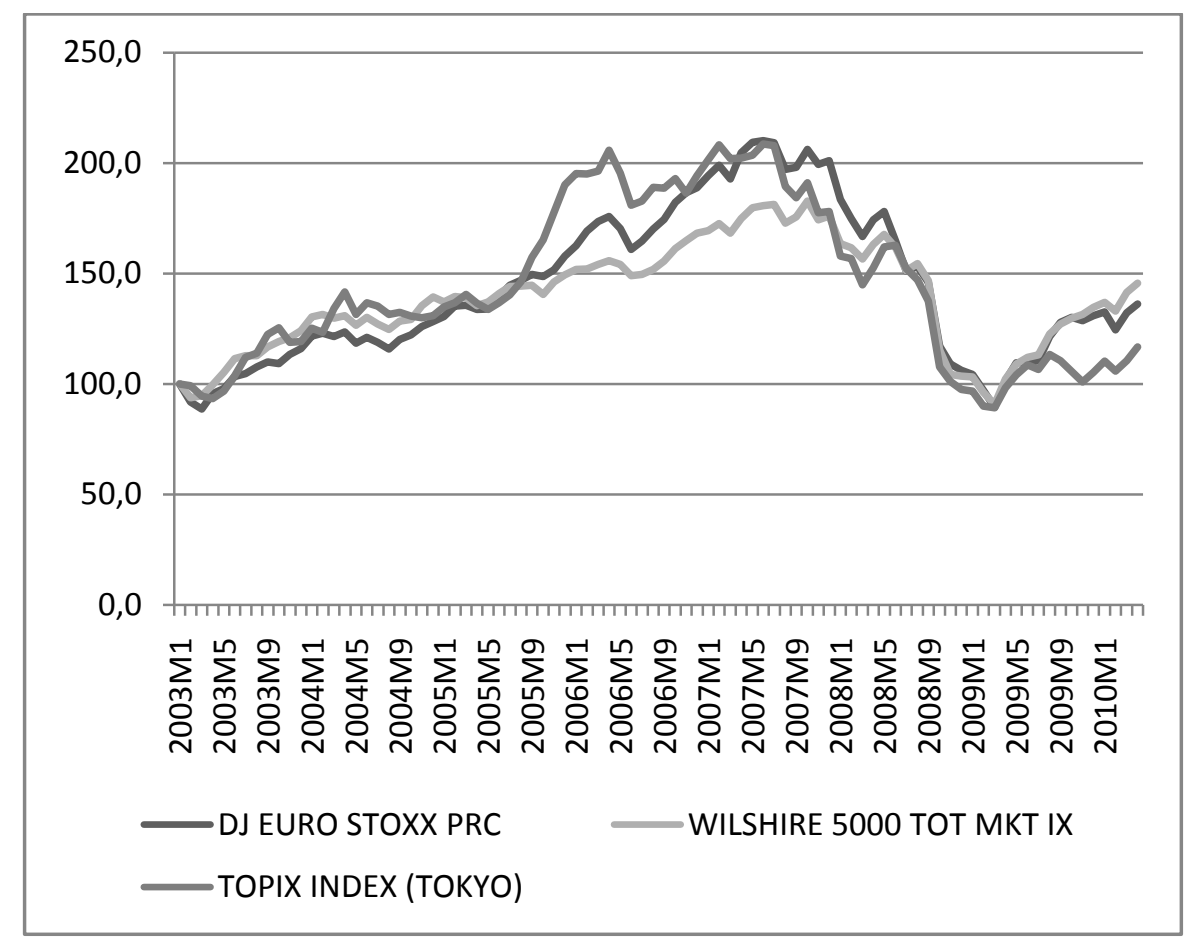

Figure 6. Stock market evolutions in the Euro area, Japan and the US. January $2003=100$. Source: World Economic Outlook, IMF 2010.

Another important factor was the impact of bursting real estate bubbles (in the US, Spain, the UK and Ireland). The readjustment in housing prices has been accompanied by a serious downturn in the construction industry, negatively affecting employment in the sector and with an indirect impact on related sectors.

With banks becoming more cautious, they tightened up loan conditions. Faced with a crisis in which one essential cause was poor assessment of the risk of borrower default, the banks strive to make adjustments and evaluate this risk better. 


\subsection{The way out of the crisis}

There has been widespread mobilisation in response to this crisis. The private sector has begun extensive restructuring and the public authorities have reacted forcefully, in ways described in the following section.

To complete our chronology of events, the global recovery that begun in the second part of 2009, is confirmed in early 2010. In April the IMF issued a rather optimistic world growth forecast for 2010 of $4.5 \%$ but also called attention that the recovery will be uneven, with emerging economies faring better than many developed countries (IMF, 2010).

Most importantly, in the summer of 2009 the financial markets have gained a new lease of life (BIS, 2009). The spread on the interbank market has returned to normal levels, and most banks reported positive net income for the second quarter of 2009 (Figure 7). The CDS spread on financial firms declined since on both sides of the Atlantic (Figure 8). ${ }^{19}$ The stock market value of banking entities more than doubled between its lowest point in March and the end of July, and most of the major stock indexes followed suit.

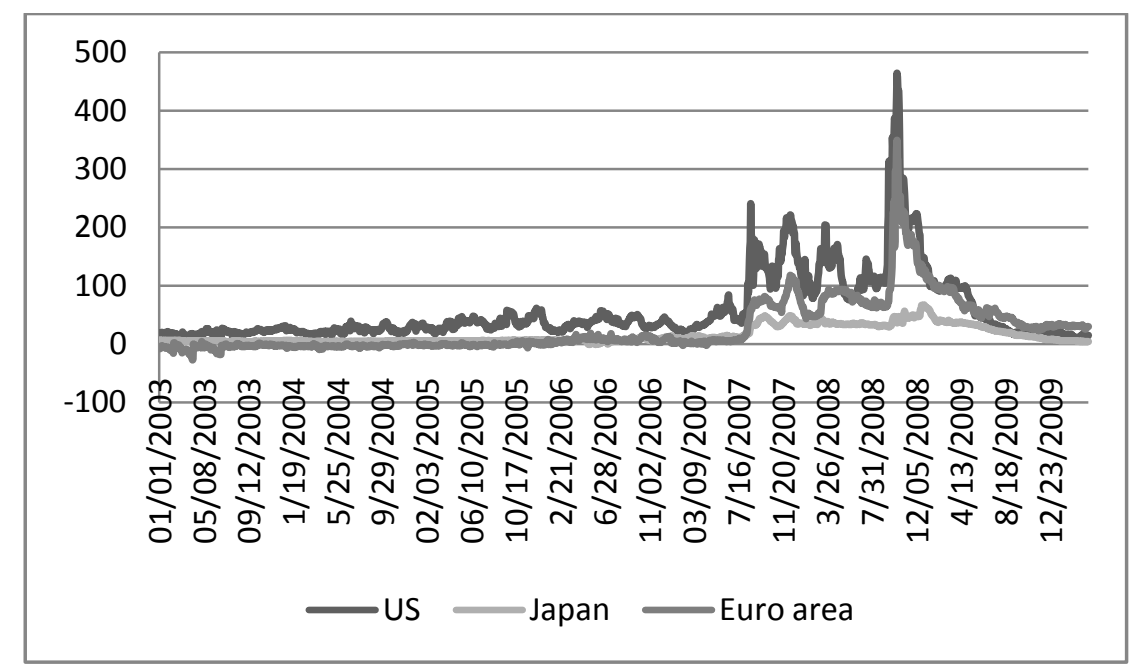

Figure 7. Interbank spreads in basis points Source: World Economic Outlook, IMF 2010.

\footnotetext{
${ }^{19}$ The CDS spread is the cost of insuring the protection buyer against the default by the reference entity, in this case, financial institutions.
} 


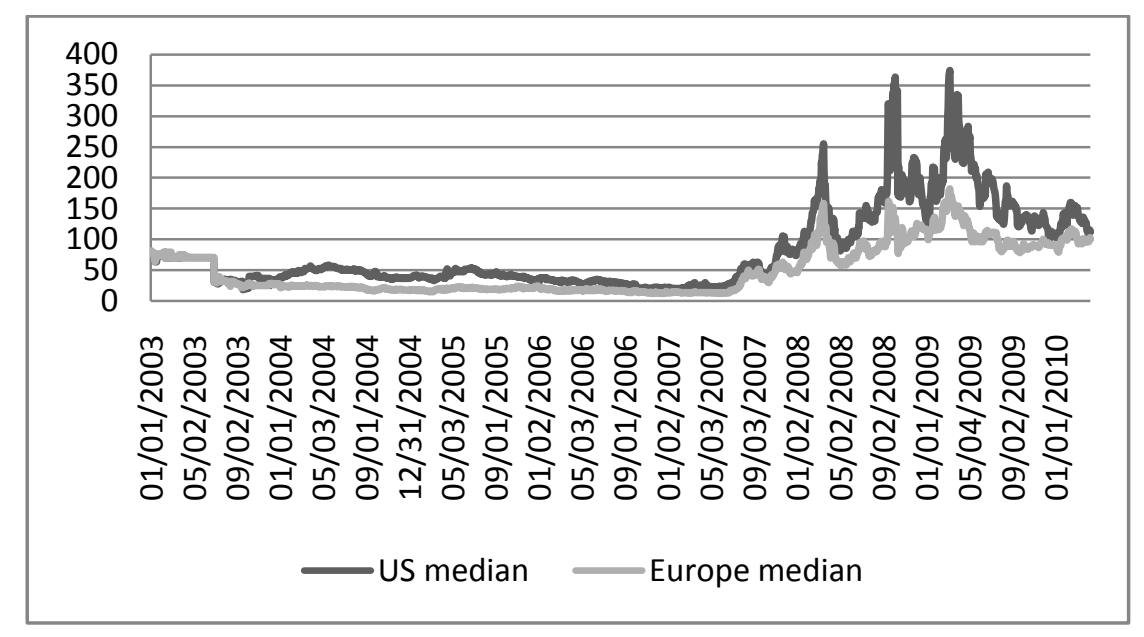

Figure 8. Bank CDS spreads in basis points (ten-year; median) Source: World Economic Outlook, IMF 2010.

The CDS catastrophe predicted in autumn 2008 has not come to pass. Many adjustments were made by the market players themselves. The notional value hedged by CDSs (USD 62 trillion in 2007) fell to USD 30 trillion by the end of 2009, chiefly due to consolidation of cross-hedges.

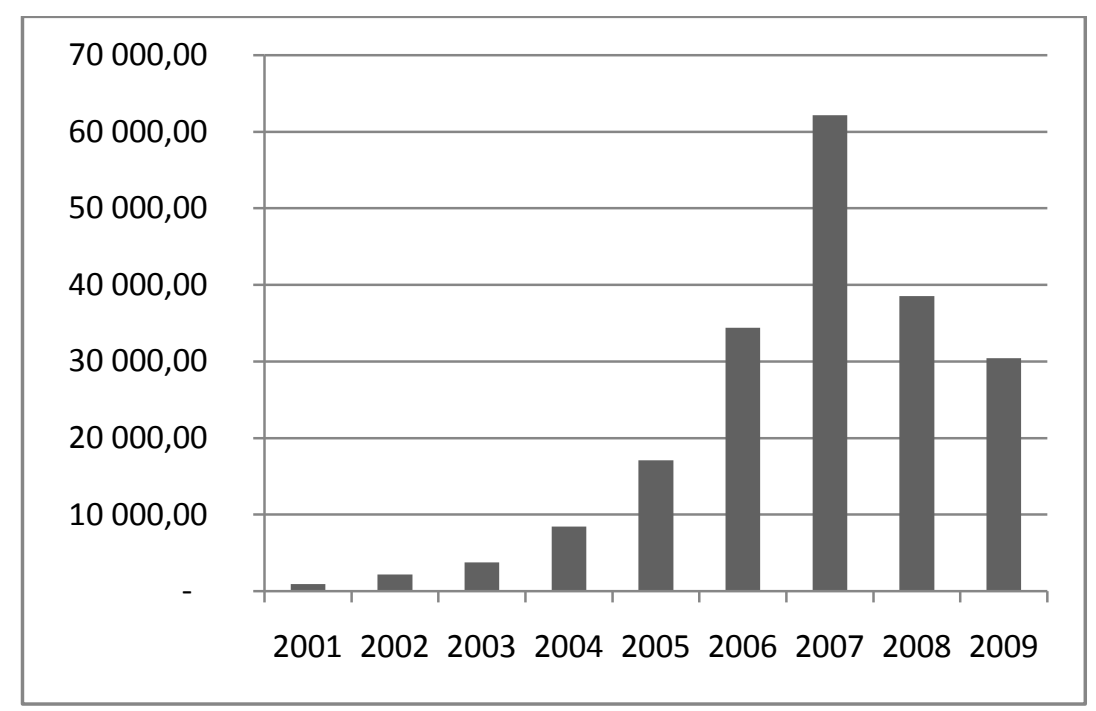

Figure 9. Notional amount of CDS outstanding in billions of USD. Source: ISDA Market Survey

If by many dimensions the crisis was over at the beginning of 2010, it will leave marks that will take time to disappear, or even worse, could originate the next crisis. In particular, the policy responses to the crisis were so ambitious that any adjustment to the normal level could prove to be extremely painful. The deterioration of fiscal policies in many countries should push up interest rates and thus take a toll on long-term growth prospects. Some governments are not exempt of the insolvency risk.

\section{How public authorities managed the crisis}

In the last few years that preceded the crisis, the deregulation doctrine seemed to accommodate well with a relatively steady growth, low inflation and prosperity in many countries (as already mentioned, many academics use to refer to this trend as the Great Moderation). In this context, a 
forth and last myth emerged, according to which governments are harmful or, at best, useless. If we listened to the Fed Chairman, Alan Greenspan, in 2005:

Whether by intention or by happenstance, many, if not most, governments in recent decades have been relying more and more on the forces of the marketplace and reducing their intervention in market outcomes. We appear to be revisiting Adam Smith's notion that the more flexible an economy the greater its ability to self-correct after inevitable, often unanticipated disturbances. That greater tendency toward self-correction has made the cyclical stability of an economy less dependent on the actions of macroeconomic policy makers, whose responses often have come too late or have been misguided. ${ }^{20}$

This myth also took a serious blow during this crisis. For sure, before the crisis public authorities played a contradictory role. A certain lack of vigilance on their part (by the competition authorities in particular) allowed some financial institutions to grow to such a size that their bankruptcy would have destabilised the entire financial market (as was the case for Lehman Brothers, and could have been the case if AIG had fallen). In the US, the public policy for encouraging home ownership irrespective of the financial health of the borrower was another contributing factor. But during the crisis it also became clear that the public authorities were the only players capable of effective action against troubles mainly caused by a general loss of trust in financial firms. Doubtless with hindsight, some measures will be seen as excessive (such as the huge public deficits in many European countries and the US) and others as useless. It must nonetheless be acknowledged that in the shortrun the cumulative effect of these measures successfully achieved the essential objective of reestablishing confidence in the financial sector and the economic system as a whole, and thus contained the magnitude of the social losses.

The aim of this section is to briefly present the more traditional measures used to shore up demand and specific measures adopted to rebuild confidence in the banking sector, bearing in mind that the effects of the two types of measure were mutually reinforcing.

\subsection{Pushing up global demand}

As already stressed, the financial crisis ultimately caused a downswing in global demand. Meanwhile, oil and commodity prices fell sharply, leading to a rapid decline in inflation worldwide. Given that price stability was not at stake, the governments and central banks were thus able to introduce traditional economic stimulus measures in a purely Keynesian approach.

In terms of monetary policy, the major central banks significantly reduced their target interest rates. The Fed target rate was pushed down from 5.25\% in 2007 to $0-0.25 \%$ in December 2008, a first in the US. The Bank of England adopted a similar policy. The European Central Bank (ECB) also reduced its main refinancing rate, from $4.25 \%$ in July 2008 to $1 \%$ in May 2009. For the first time in their modern history, the central banks made full use of the weapon of interest-rate reduction and had then to consider "unconventional" actions. ${ }^{21}$

As far as fiscal policy is concerned, in the US the Bush administration brought in a significant tax cut in 2008. In February 2009, the new Obama administration introduced a USD 787 billion 2-year rescue package comprising spending to improve infrastructures and scientific research, public grants (for health, education, and protection for the unemployed), and tax cuts for households and businesses.

\footnotetext{
${ }^{20}$ Alan Greenspan International imbalances, Remarks before the Advancing Enterprise Conference, London, England, December 2, 2005www.federalreserve.gov/boarddocs/speeches/2005/200512022/default.htm.

${ }^{21}$ Notice that the dominant New Keynesian model used for monetary policy analysis and simulation has little to say about the impact of measures other than changes in the interest rate.
} 
Across the Atlantic, in December 2008 European Union member states adopted a coordinated stimulus plan worth $1.5 \%$ of their combined GDP ( $€ 200$ billion).

The strong demand stimulus helped avoiding an even sharper decline in activity in all countries, and through the export channel, contributed to stabilize the global economy. It also helped stabilizing the financial sectors by limiting the number of bankruptcies (and thus the losses for those banks that sold CDS on these companies).

Unfortunately, this generous State support came with a cost: deficits reached record heights in many countries, and pushed public debts on untested time path. In the past, Japan has showed that a developed country can live for many years with a debt to GDP ratio as high as $175 \%$. Yet the world has changed after 2009. Today all governments aim at financing high and rising amounts of debts (see Table). Many (European) countries are heading toward the 100\% debt to GDP threshold within the next two years. According to official forecasts, the US public debt could reach $90 \%$ by 2020 (Bohn, 2010). So governments must compete for an amount of savings that has no particular reason to rise in a significant way. Nervous investors are watching for the slightest sign of weakness to ask for higher risk premia.

\begin{tabular}{|l|c|c|}
\hline & Public deficit & Public debt \\
\hline United States & -11.9 & 60 \\
\hline Japon & -7.7 & 192 \\
\hline Selected EU countires & & \\
\hline UK & -14.5 & 68.5 \\
\hline France & -7.5 & 79.7 \\
\hline Germany & -4.6 & 77.2 \\
\hline Italy & -5.3 & 115.2 \\
\hline EU “high risk" countries (as of April 2010) & \\
\hline Portugal & -6.7 & 77.4 \\
\hline Ireland & -12.2 & 65.8 \\
\hline Greece & -12.7 & 112.6 \\
\hline Spain & -9.6 & 54.9 \\
\hline
\end{tabular}

Table 1: Public debt and public deficit as a percentage of GDP in selected high-income countries, 2009. Source: OECD and CIA Factbook

In mid 2010, Greece faced huge difficulties in refinancing some tranches of its $120 \%$ of GDP debt and only a coordinated action at the EU level allowed to avoid immediate default (before the intervention, the two-year interest rate on Greek debt reached 12\%). The intervention involved an EU managed 110 billion euro loan to Greece, which entered under the IMF monitoring process for distressed countries, and a dramatic decision of the ECB to start buying sovereign debt (they probably bough substantial amounts of Greek debt). 
Investors seem to be particularly worried about the sustainability of public debts of Spain, Portugal and Ireland, in particular due to the modest credibility of their deficit reduction plans. In June 2010 the European Union has created a Special Investment Vehicle with the purpose of borrowing euros in the international marketplace with a 440 billion euros guarantee provided by fiscally sounder countries (and some 150 billion from the IMF), in order to lend money to those governments that may face temporary difficulties in financing their debt.

\subsection{Restoring trust}

Much has been written about the measures taken to rebuild confidence, as they ventured off the beaten track trodden by the usual action in macroeconomic crises. To be fair, most of these measures were inspired by the policies implemented by the Nordic countries during their 1990s banking system crisis. A distinction can be drawn, for the purposes of presentation, between action by governments and action by the central banks, although in all countries these bodies acted in coordination.

One of the US government's initial reactions was to attack the root of the problem, i.e. the rise in the default rate on subprime mortgage loans. In compliance with the Bush administration's December 2007 plan, the poorest households were allowed to amend the terms of their loans and benefit from the special promotional interest rate for longer than initially promised (generally two years). In February 2009, the new US administration decided to reinforce support for the most exposed homeowners, to stem the wave of default and repossession. Unfortunately, these measures do not seem to have been very effective, as the income of the households fell further than predicted.

For deposit banks, reserves equivalent to more than $8 \%$ of loans outstanding is generally perceived as proof of good risk management (this thumb rule is in line with the former Basel I regulation, still in force for US banks). A large number of US and European banks had to write off losses resulting from the plummeting value of the CDOs they held, and saw their equity fall below the accepted level. ${ }^{22}$ Several banks tried to raise funds on the private market to restore their capital, but the success of the exercise was very limited in the height of the crisis.

Two types of public interventions are possible to improve a bank's solvency ratio: either buying the bank's dubious assets at a high enough price, or supplying new equity, for instance by acquiring a shareholding. It is possible to do both simultaneously.

In September 2008, the US administration launched the Troubled Assets Relief Programme (TARP), with an initial budget of USD 700 billion with the aim of buying such "toxic assets". But this measure could not be implemented, as there was no effective way of valuing these assets following the disappearance of the secondary market. Only Switzerland has set up a "bad bank", which purchased $€ 25$ billion of toxic assets from UBS in 2008.

So, following the British example, at the end of 2008 the US government and most European governments decided to recapitalise banks whose falling reserves were dangerously increasing the risk of insolvency. The principal method used was the purchase of preference shares (or more rarely, ordinary shares).

\footnotetext{
${ }^{22}$ According to IMF estimates (as to April 2010), the banking system write-off from the onset of the crisis through 2010 reached the "astronomic" figure of 2.3 trillion USD (IMF 2010).
} 
More in detail, in the US, the government modified the TARP to allow USD 700 billion to be used for bank recapitalisation under its Capital Purchase Program. In the period to March 31, 2009, some 500 banks had benefited from capital injections (through preference shares). An important moment in the management of the crisis came when ten major banks that had received public funding decided to reimburse the money in June 2009. By January 2010, most of the banks have reimbursed the public money, and the expected total bill on this programme should not exceed 90 billions dollars (mostly from loss making investments in carmakers and AIG). ${ }^{23}$

\section{BOX 2: Preferred shares}

This type of share pays regular fixed dividends, operating in the same way as a bond coupon except that there is no final maturity. Preference shares rank higher than ordinary shares for dividend payments and in the event of liquidation following bankruptcy, but do not carry voting rights. This cannot really be considered as "nationalisation" even though in some cases the government has become the majority contributor to banks' equity. In proceeding to recapitalisation through issuance of preference shares, the governments have negotiated high dividends and imposed restrictions on management salaries and dividend distribution to ordinary shareholders; this gives the banks a strong incentive to repurchase the shares at the end of the minimum period stipulated in the contract (generally 5 years). Given the fixeddividend structure, the market value of these shares varies inversely with the market interest rate, and therefore the shareholder cannot benefit from any increase in the firm's market value. To remedy this, the preference shares generally have warrants attached for subscription of one ordinary share at a predefined price, so that if the ordinary share rises in value, its owner (here the government) can make a capital gain.

It should be emphasized that in the US, the government focused its efforts on saving or facilitating successful absorbing of major Wall Street investment banks, and a small number of giants from the financial sector (the insurance company AIG, the bank Citigroup and the specialized firms Freddie Mac and Fannie Mae), but did not intervene to save commercial banks on the brink of insolvency. European governments have taken their support for banks to extremes in an attempt to prevent any bankruptcy, even for second-class banks. This happened to Northern Rock in England, which was nationalised as a matter of urgency. Hypo Real Estate and IKW in Germany (a public bank), as well as the Franco-Belgian bank Dexia, received substantial inputs of public capital that helped them to narrowly avoid filing for bankruptcy. The French government provided a substantial amount of funds to the main four national banks, although it was not obvious that these banks did face insolvency problems; this move has probably discouraged potential buyers for these firms.

Apart from the threat of insolvency, banks had to cope with difficulties in financing their short-term operations. As already mentioned, the interbank credit market (where banks lend and borrow cash between them) dried up in the aftermath of Lehman's banckrupcy. To support this market, many governments have set-up public guarantees for short-term interbank loans. In 2010 all countries terminated these guarantees, without having spent one penny.

Turning now to central bank's action, they rose to the challenge in their role as supplier of liquidity in a crisis situation (or "lender of last resort"). As operations dried up on the interbank market where banks seek short-term financing, the central banks decided to step in to bolster the market. For so doing, in the US, banks were invited to apply to the Fed for collateralised loans within the framework of the "discount window" facility, and the term of those loans was extended to three months. Meanwhile the ECB gradually raised the volume of liquidity available to banks through traditional one-week reverse-repo operations and broadened the range of acceptable collateral; in a more

\footnotetext{
${ }^{23}$ Cheap as chips, The Economist, January 16th, 2010.
} 
spectacular move, they extended the duration of longer-term credits up to one year, and let banks freely decide on the amount they want to borrow.

The Fed (and the Bank of England) also adopted a whole set of more unconventional measures to support credit development in a context where they could not further reduce the short term interest rate once that it reached the zero thresholds. For example, it decided to make three-month loans to money market investment funds, agreed to purchase 3-month debt certificates issued by sound nonfinancial firms, bought some of the debt of the Freddie Mac and Fannie Mae, and end up by buying long-term treasury bonds. The direct result of these measures has been an unprecedented increase in the balance sheet value of the central banks.

By 2010 time has come to unwind the generous support of the central bank to commercial banks and other exceptional measures, without imposing too much stress on financial markets. Consensus of central bankers is to give up to all special programmes that are no longer used by banks. The US and the UK ceased their programmes of buying long-term Treasury bonds. The European and mainly Greek debt problems confronted the ECB with a difficult dilemma. While in 2009 the ECB indicated that long-term repo operations should be terminated, in April 2010 they postponed indefinitely this decision. Furthermore, they agreed on directly buying sovereign debt on the secondary market, a measure that contradicts if not the legal framework, at least the verbal commitment of the ECB to Bundesbank style rigor. The fact that at the same time the euro depreciated sharply against the dollar is probably more than a coincidence. Some observers surmised that the ECB decision was driven mainly by political pressure to rescue European banks that hold the largest chunk of Greek debt.

One important lesson from this crisis management episode is the positive contribution of governments and central banks in the late 2008 by immediately mending any market short of liquidity. The most important consequence of this resolute action was a clear signal sent to market players: that the government or the central bank would not let the system collapse even if ultimately they must take the losses. The signal was credible enough to restore trust and the good functioning of the markets; hence the public authorities had not to bear any substantial losses.

It must be seen whether this massive rescue plan will prompt financial institutions to take even higher risks in the years to come, what many observers refer to as the moral hazard problem. More worrisome, some European governments, but also the US might have pushed the spending lever too much. An adjustment in the fiscal position is now unavoidable, since investors will sanction all governments that cannot commit on a sustainable public debt path. But such adjustments come with their own costs in terms of postponed growth.

\subsection{Regulation of the financial system}

A last dimension of public action is regulation, or the design of a set of rules aiming to support the fluidity and transparency of market trades. The main role of intelligent regulation is to prevent crises, or in the terms used in the introduction, to make sure that bad equilibria cannot arise. The 20072009 crisis was interpreted by many observers as the result of a shortage of regulation in financial markets. Others pointed out that many current difficulties stem precisely from the existing regulation or public intervention.

Probably, both experts make an interesting point. Clearly, antitrust regulation is much needed in a financial sector where barriers to entry are substantial (Stiglitz, 2010). Some regulation might be needed to reduce the amount of risk born by banks in normal times and to enhance transparency. 
Yet, the design of such regulation is not an easy task, as long as nothing guarantees that the regulators have better information about risks inside the system than private agents. To take an example, the regulation in force in the 2000s was broadly based on those risk grades issued by rating agencies, which were considered infallible by the public authorities. As a consequence, many European banks have filled their books with triple-A CDOs that turned out to be worthless. Should banks have been free to choose the measure of risk, these mistakes could have been avoided.

In normal times, banks are extremely opaque institutions and this opacity is part of their business model (Morgan, 2002). As already mentioned, during the crisis, the incapacity to sort good form bad institutions brought about substantial financial distress. One important tool used during this crisis to address this imperfect information challenge was stress tests. More in detail, in the late 2008 , the US Fed undertook the process of screening the operation risk of the large financial institutions (for 19 largest banks with respect to managed assets) and was followed on a short notice by European governments. Basically, such tests provide empirical estimate of the additional capital banks should hold in order to survive to a catastrophic scenario. Of course, the outcome depends to a large extent on the nature and size of the simulated shock. For instance, the US tests considered under the most averse scenario a substantial decline in GDP (more than 3\%), persistent unemployment at $10 \%$ and a further decline in housing prices. fall in GDP of $10 \%$ over the next year. ${ }^{24}$ When in Mai 2009 the results of these tests were made public and appeared to be extremely positive for a majority of the 19 banks under scrutiny, the last tensions existing in the market disappeared. The US regulator decided to disclose the additional capital requirement needed to cope with the most adverse scenario for each bank. The European regulator communicated only an average grade and a global qualitative assessment, considering at that time that disclosing bank-specific information is an uncompetitive practice.

The tension between the US and the EU regulators with respect to the "transparency" vs. "industrial protection" rose gradually. In June 2010 the EU ended up by authorizing the Committee of European Bank Supervision to communicate results of the stress tests for each bank (a move first unilaterally undertaken by Spain), but it not clear yet whether national legislation will allow for this measure to be implemented. At the same time, many observers question the validity of a stress test that rules out the possibility of default on public debt by a euro-area member country.

These days many expert national and international organizations are delivering an important effort of understanding this crisis and contribute to draft the rules of a new financial architecture. Main goals are to improve the overall transparency of the financial markets and operations, including fighting tax evasion and money laundering via tax havens, improving the quality of information provided by the main players, limiting the amount of risk borne by banks, improving the supervision of the financial system.

Despite the populist rhetoric of some political leaders, in general governments appear to have confidence in the banking system's ability to learn from past errors and adopt better management practices. As a consequence, they are not necessarily seeking to extend constraints much beyond the measures already accepted or introduced by the profession. Most proposed measures aim at limiting the amount of risk that banks can take (and, due to the standard trade-off between risk and return, also limit their profits).

The Basel Committee and the International Accounting Standards Board (IASB) have stepped up their work to give greater consideration to risk, particularly in relation to off balance sheet entities. A significant action in the realm of financial regulation is being carried out by the G20 within the

${ }^{24}$ See: The Supervisory Capital Assessment Program: Design and Implementation, Board of Governors of the Federal Reserve System. On line at: www.federalreserve.gov /newsevents/ press/bcreg/ bcreg20090424a1.pdf. 
framework of the newly created Council of Financial Stability (September 2009). The G20 gathers twenty developed and big developing countries, which share the idea according to which measures for increasing financial stability should be implemented at a global level. After a first meeting in London in April 2009, leaders of the G20 countries met again in September 2009 in Pittsburgh, at a time where tensions in the financial markets faded away. The agreed rules were minimalist. Many governments agree on that the central banks' financial oversight attributions should be reinforced. Most important, banks will be required to build larger capital reserves, and a leverage ratio will be implemented before 2012. Top officials in France and Germany argued in favour of capping traders' bonuses. The G20 could not reach any international agreement on that proposal, which was left to the discretion of national authorities. Several countries (US, UK, France) have since imposed some taxes on the traders' 2009 bonus; in June 2010 the US Administration urged financial institutions to take more aggressive steps to make sure that pay packages are "consistent with the soundness of the organization", but did not impose any further limits.

In the years before the crisis, many large banks, both in the US and Europe, set up large proprietary trading desks, actually mimicking the activity of hedge funds. In January 2010, a US Committee run by the former Fed chairman Paul Volcker, recommended that banks should be forbidden to carry out such kind of proprietary trading. This would also limit the amount of risk that banks can take on their balance sheets.

Finally, noteworthy positive action for standardisation of derivatives has also been taken by the International Swaps and Derivatives Association. To limit the risks related to the CDS market, the US Administration and European Commission decided to support creation of private clearing houses to centralise the two-way trading involved in CDSs.

On the other hand, governments have been surprisingly silent on the need to enforce competition in the banking and financial sector. During this crisis, many difficulties concerned establishments previously considered "too big to fail": financial giants that were often badly managed but would have caused major disruption if they had gone bankrupt. So far, the only proposal directly aiming to improve the governance of the large firms is to create a fast-track procedure through which governments can liquidate in a neat way too-big-to fail firms should they become insolvent. Yet there are little discussions of how to foster competition within the banking sector. The banking sector in many countries has all the characteristics of an oligopoly. Limiting banks size, tightening the competition authorities' supervision and opening the borders to true competition from abroad would help dismantling it, to the benefit of the consumers. ${ }^{25}$ Stiglitz (2010) identifies a more powerful competition between financial institutions of a smaller size as one important way to increase the resilience of the financial sector to shocks.

\section{Conclusion}

As in resolution of past crises, during the 2007-2009 period the most powerful anti-crisis weapon took the form of adjustments implemented by the private players themselves under the impact of market forces. We have already witnessed the disappearance of investment banks as such; the large diversified banks are redesigning their strategy in order to focus on safer activities. ${ }^{26}$ Banks are also strengthening their proprietary risk management systems.

\footnotetext{
${ }^{25}$ Actually, during this crisis, the European governments have looked favourably on internal mergers. In Britain, the number one mortgage lender HBOS was taken over by Lloyds TSB, the country's fifth-largest bank, and still benefited from the government's recapitalisation plan.

${ }^{26}$ As a consequence, many top traders involved in high risk trades preferred to leave their investment departments and joined hedge funds.
} 
On the other hand, a move towards concentration in the banking sector can now be observed, essentially inside national frontiers. Little progress is made toward increasing competition in the banking sector, as if in these difficult times for the financial profession, national policymakers were more concerned about banks' earnings and banks' survival than consumers' welfare.

While it is too soon to venture a precise tendency for the future organization of the financial system, this crisis taught us some hard lessons that will guide the restructuring process:

- It showed that developed countries are not insulated from the curse of multiple equilibria, and that a sharp reversal in individuals' expectations can bring about major disruption of financial markets.

- Far from diluting risk, the new financial instruments were at the origin of new form of risks, unsuspected before, such as the risk of bankruptcy of protection sellers in CDS contracts, or the worthless CDOs when the value of the underling asset collapses;

- Shocks originated in financial markets do propagate to the real sector and thus entail large social losses;

- The public administration (government and central bank) can help overcoming such crisis of trust by rapid, coordinated, comprehensive and limited in time interventions. In the longer run, the main challenge for policymakers is to maintain competition alive in the financial sector.

The fifteen years leading up to the crisis were years of great prosperity: output and labor productivity rose constantly, and the performance of the labour markets improved all over the world, one effect being a sharp decline in unemployment. As these achievements took place in a period of significant market deregulation, the public authorities appeared to be destined for gradual withdrawal from the economic sphere, whatever the extent of this withdrawal. But in the critical phases of this crisis, it has been obvious that the public authorities - governments and central banks - were the last stronghold of stability. Events have shown that the authorities should maintain and reinforce their capacity for action in a time of crisis - for sure, the aim is not to expand the public sector, but to equip policymakers with tools for rapid intervention in case of economic troubles. Such tools range from standardization, committed expenses and guaranties, to enhancing transparency by shedding light on normally hidden activities within banks.

Before this crisis, public authorities and private players had delegated risk assessment to the three major ratings agencies. These agencies appear to have failed once again in assessing the risk on structured products, just as they failed in 2000-2001 to report a correct assessment of the risk associated with shares in companies such as Enron, Qwest and WorldCom (Vranceanu, 2005). Two outrageous errors in ten years is too much for players occupying a pivotal role in the worldwide financial system. An in-depth reform of the risk assessment system is thus more than necessary, and reflection on the matter is only just beginning. Many solutions can be considered, from creation of new agencies to foster genuine competition, or total abandonment of this type of credit risk rating to the benefit of producing in-house, decentralised information. As an example of private production of information, some banks have issued unrated CDOs, and fully disclosed the elements needed by potential buyers to assess the risk of the portfolio without having to rely on a rating agency.

Whenever a market overheats, certain individuals are more tempted to abuse the system and commit acts both immoral and illegal. In the US, Bernard Madoff, an established fund manager, had in fact introduced an illegal pyramid scheme that resulted in net losses of USD 13 billion for investors. The Texan financier Allan Stanford is accused of a similar type of fraud, in which investors lost a total of approximately USD 8 billion. In France, Jerôme Kerviel, a trader with the Société Générale, took unauthorized bets that ultimately led to a loss of 4.9 billion euros for the bank. Nonetheless, these 
are exceptions and seem to be epiphenomena. Fraud and swindling are not the distinctive mark of this crisis - in fact, a much higher number of cases of fraud (earnings manipulation) were registered during the 2000-2001 dotcom crisis than this time.

While broadly speaking the law has been respected, the state of mind of the financial sector as a whole is a problem. What justification can there be for the "casino" attitude that appears to be the watchword in many banks, which strictly speaking are supposed to manage their clients' deposits and shareholders' interests prudently and within a long-run perspective? What explanation can there be for the European banks' rush on US-produced CDOs? Supposing that returns are visible but the risk is not, maybe the fragile banks sought to offer the same returns as the sounder banks, taking more risks simply to attract investors. But microeconomic explanations might not provide the answer to the underlying question of why, in the world of finance, players sometimes manage to become disconnected from the world they live in, caring only for abstract money performance which has nothing to do with the constructive search for profit going on everywhere else in the economy (Solomon, 1992).

After this crisis, which could have turned into a much more dramatic systemic meltdown, the whole world is in the position of a driver who has narrowly avoided a serious road accident thanks to an almost animal instinct for survival. Like the driver who has escaped a tragic fate, we are left wondering what we should do to ensure we never find ourselves in the same position. Change things: yes, but how? The solutions of restrictive regulations, or even central planning, are not compatible with sustainable growth. Furthermore, some regulations themselves can explain the additional volatility. Nor is extreme deregulation: in the universe of finance, it leads to the emergence of giant institutions, sometimes fragile because badly-managed. Frustrating though it might be, no-one currently has a satisfactory answer. After the Great Crisis, three years passed before Keynes published his General Theory, and another ten years before it became a benchmark work. This record is unlikely to be beaten. To end on an optimistic note, what should be remembered from this crisis is the general mobilisation of all stakeholders, and a proven resilience in the economic system.

\section{REFERENCES}

Ashcraft, A. B. and T. Schuermann, 2008, Understanding the securitization of subprime mortgage credit, Federal Reserve Bank of NY Staff Report, nr. 318.

Besancenot, D. and R. Vranceanu, 2010, Financial distress and banks' communication policy in crisis times, Romanian Journal of Economic Forecasting, 13, 1, pp. 5-20.

Blanchard, O., 2010, The state of macro, Annual Review of Economics, 1, pp. 209-228.

BIS, 2009, International banking and financial market developments, BIS Quarterly Review, June 2009.

Brunnermeier, M. K., 2009, Deciphering the liquidity and credit crunch 2007-2008, Journal of Economic Perspectives, 23, 1, pp. 77-100

Bohn, H., 2010, The economic consequences of rising US government debt: Privileges at risk, CESIFO Working Paper, nr. 3079, June. 
Coval, J., J. Jurek, and E. Stafford, 2009, The economics of structured finance, Journal of Economic Perspectives, 23, 1, pp. 3-25.

Clarida, R., Gali, J, Gertler, M, 1999, The science of monetary policy: A New-Keynesian perspective, Journal of Economic Literature, 37, December, pp. 1661-1707.

Cúrdia, V. and M. Woodford, 2009, Credit frictions and optimal monetary policy, BIS Working Papers, nr. 278.

Demigüç-Kunt, A. and E. Detragiache, 1998, Financial liberalisation and financial fragility, IMF Working Paper nr. 98/83.

Diamond, D. W and R. G. Rajan, 2009, The credit crisis: conjectures about causes and remedies, American Economic Review: Papers and Proceedings, 99, 2, pp. 606-610.

Diamond, D. W. and P. H. Dybvig, 1983, Bank runs, deposit insurance and liquidity, Journal of Political Economy, 91, 3, pp. 401-419.

Englund, P., 1999, The Swedish banking crisis: roots and consequences, Oxford Review of Economic Policy, 15, 3, pp. 80-97.

FASB, 2009, A regulatory response to the global banking crisis, Financial Service Authority, DP 09/2, March 2009. Online at: www.fsa.gov.uk/pubs/discussion/dp09_02.pdf.

Gali, J., 2008, Monetary Policy, Inflation, and the Business Cycle, Princeton University Press.

Galí, J. and L. Gambetti, L., 2009, On the sources of the Great Moderation, American Economic Journal: Macroeconomics, 1, 1, pp. 26-57.

Giannone, D., M. Lenza and L. Reichlin, 2008, Explaining the Great Moderation: It is not the shocks, Journal of the European Economic Association, 6, 2-3, pp. 621-633

IMF, 2010, World Economic Outlook, April 2010, International Monetary Fund, Washington DC. Online at: www.imf.org/external/pubs/ft/weo/2010/01/index.htm.

Kiff, J. and P. Mills, 2007, Money for nothing and checks for free: recent developments in the US subprime mortgage markets, IMF Working Paper, 2007/188.

Krishnamurthy, A., 2009, Amplification mechanisms in liquidity crises, NBER Working Papers, w15040, on line: www.nber.org/papers/w15040.

Minsky, H., 1986, Stabilizing an Unstable Economy, Yale University Press, New Haven.

Miller, M. and J. E. Stiglitz, 2010, Leverage and asset bubbles: averting Armagedon with Chapter 11? Economic Journal, 120, pp. 500-518.

Morgan, D. P., 2002, Risk and uncertainty in an opaque industry, American Economic Review, 92, 4, pp. 874-888.

Pomfret, R., 2010, The financial sector and the future of capitalism, Economic Systems, 34, pp. 22-37.

Reinhart, C. M. and K. S. Rogoff, 2008, Is the 2007 U.S. sub-prime financial crisis so different? An international historical comparison, NBER Working Paper, nr. 13761. 
Rochet J.-C. and J. Tirole, 1996, Interbank lending and systemic risk, Journal of Money, Credit and Banking, 28, 4, pp. 733-762.

Solomon, R. C., 1992, Ethics and Excellence, Oxford University Press, Oxford, UK.

Stiglitz, J. E., 2010, Freefall. Free Markets and Sinking of the Global Economy, Alen Lane, UK.

Vranceanu, R., 2005, Deregulating dishonesty. Lessons from the US corporate scandals, In: D. Daianu and R. Vranceanu (Eds.), Ethical Boundaries of Capitalism, Ashgate, UK, pp. 219-238. 


\section{ESSEC \\ BUSINESS SCHOOL}

CENTRE DE RECHERCHE

RESEARCH CENTER

Les Documents de Recherche de

l'ESSEC Business School sont disponibles à l'adresse suivante :

http://www.essec.fr/professeurs-et-recherche/larecherche/publications.html

ESSEC Working Papers are available at the following address:

http://www.essec.edu/faculty-and-research/research/publications.html 
Pour tous renseignements :

- Centre de Recherche/Research Center Tél. 33 (0)1 34433091

research.center@essec.fr

- Visitez notre site www.essec.fr

ESSEC BUSINESS SCHOOL PARIS

AVENUE BERNARD HIRSCH - BP 50105 CERGY

95021 CERGY-PONTOISE CEDEX - FRANCE

TÉL. +33 (0)134433000 - FAX +33 (0)134433001

www.essec.fr

ESSEC EXECUTIVE EDUCATION

CNIT - BP 230

92053 PARIS LA DÉFENSE - FRANCE

TÉL. +33 (0)146924900 - FAX +33 (0)146924990

http://formation.essec.fr

ESSEC BUSINESS SCHOOL, SINGAPORE CAMPUS

100 VICTORIA STREET - NATIONAL LIBRARY BUILDING \#13-02

SINGAPORE 188064

TÉL. +65 68849780 - FAX +65 68849781

www.essec.edu

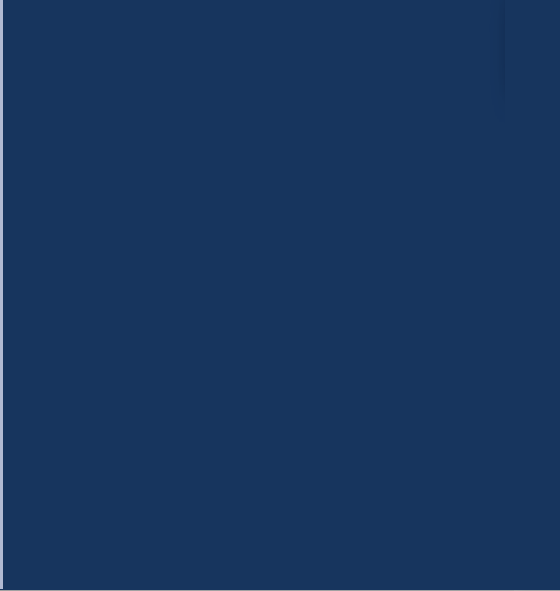

